\title{
UJI AKTIVITAS ENZIM AMILOGLUKOSIDASE DARI Aspergillus niger PADA KOMBINASI pH DAN SUHU YANG BERVARIASI
}

\author{
Fatmawati Nur* \\ *Jurusan Biologi Fakultas Sains dan Teknologi \\ Universitas Islam Negeri (UIN) Alauddin Makassar \\ email: fatenurkhalik@yahoo.com
}

\begin{abstract}
Abstrak: Penelitian ini dilakukan untuk menguji aktivitas enzim amiloglukosidase yang dihasilkan oleh Aspergillus niger pada kombinasi $\mathrm{pH}$ dan suhu yang bervariasi, yaitu pada $\mathrm{pH} 4.5,5.0$, dan 5.5, suhu $35{ }^{\circ} \mathrm{C}, 40{ }^{\circ} \mathrm{C}, 50{ }^{\circ} \mathrm{C}, 55^{\circ} \mathrm{C}, 60{ }^{\circ} \mathrm{C}$, dan $65{ }^{\circ} \mathrm{C}$, dengan tujuan mengetahui kombinasi $\mathrm{pH}$ dan suhu yang optimum untuk aktivitas maksimum enzim tersebut. Pengujian aktivitas enzim amiloglukosidase dilakukan pada jam ke 96 waktu fermentasi pada media cair yang diinkubasikan pada penangas goyang, suhu kamar, dan $\mathrm{pH} 4.5$ dengan metode Sacharifying, tiga kali ulangan dan dianalisis dengan Rancangan Faktorial, Rancangan Acak Kelompok (RAK), kemudian dilanjutkan dengan uji Wilayah Berganda Duncan (WBD). Hasil penelitian menunjukkan bahwa Aktivitas enzim amiloglukosidase maksimal terjadi pada kombinasi suhu $60^{\circ} \mathrm{C}$ dan $\mathrm{pH} 5.0$ sebesar 15.6493 (unit $/ \mathrm{ml}$ ), dan aktivitas enzim amiloglukosidase minimal terjadi pada kombinasi suhu $65^{\circ} \mathrm{C}$ dan $\mathrm{pH} 5.5$ sebesar 7.9823 (unit/ml).
\end{abstract}

Kata Kunci: Aktivitas enzim, Amiloglikosidase, pH, Suhu

\section{PENDAHULUAN}

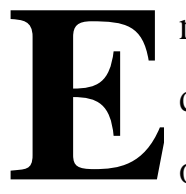

nzim adalah senyawa organik berupa protein yang dihasilkan oleh sel-sel hidup dan berperan sebagai katalisator pada reaksi kimia yang berlangsung dalam organisme, memiliki sifat dan spesifikasi tertentu (Gaman, 1992). Komponen enzim dapat berupa protein murni atau gabungan antara protein dengan gugus kimiawi lainnya. Bagian enzim yang terdiri dan protein bersifat termolabil (tidak tahan panas) diberi nama apoenzim. Sedangkan bagian lain yang bukan protein bersifat termostabil (tahan panas) diberi nama gugus prostetik (bagian yang aktif). Apoenzim dengan gugusan prostetik merupakan satu kesatuan yang disebut holoenzim(Kertesz 1976). 
Seperti halnya semua protein, enzim akan terdenaturasi oleh panas, terepresikan oleh etanol, dan tak terdialisis (Pelczar, 1985). Selain itu, enzim memiliki sifat-sifat yang khusus meliputi spesifitas yang tinggi dengan mengkatalisis satu reaksi, aktivitasnya dipengaruhi oleh suhu, $\mathrm{pH}$, memerlukan aktivator, dan dalam jumlah yang kecil dapat mengkatalisis substrat yang besar (Gaman, 1992).

Tiap sel mengandung enzim sehingga dapat diperoleh dari jaringan tumbuhan, hewan, dan mikroorganisme yang terseleksi (Smith, 1993). Sekalipun semua enzim pada mulanya dihasilkan di dalam sel, beberapa mikroba dapat mengekskresikan enzimnya melalui dinding sel dan dapat berfungsi di luar sel (Pelczar, 1985). Enzim yang dikeluarkan oleh mikroba ke lingkungan, lazim disebut enzim ekstraselluler (Smith, 1993). Fungsi utamanya ialah melangsungkan perubahan seperlunya pada nutrien di sekitarnya sehingga memungkinkan nutrien tersebut memasuki sel (Pelczar, 1985).

Salah satu jenis enzim ekstraselluler yang penting adalah amiloglukosidase yang digunakan dalam bidang produksi alkohol, roti, juice, dan pati. Mikroba yang berkemampuan baik untuk menghasilkan enzim ini adalah jenis Aspergillus niger, Aspergillus oryzae, dan Endomycopsis bisfora. (Smith, 1993).

Hasil penelitian terdahulu memperlihatkan produksi amiloglukosidase oleh Aspergillus niger L.51/NRRL All-164 dengan molases sebagai sumber karbon, menunjukkan kondisi optimal produksi pada suhu $35^{\circ} \mathrm{C}, \mathrm{pH} 4.5$ (Rahman, 1992). Tetapi pada umumnya aktivitas enzim amiloglukosidase optimal bekerja pada kisaran suhu $40-60^{\circ} \mathrm{C}$ dan $\mathrm{pH}$ berkisar 4.5 - 5.0 (Winarno, 1995).

\section{TUJUAN PENELITIAN}

1. Untuk mengetahui aktivitas maksimal enzim amiloglukosidase dari Aspergillus niger pada kombinasi suhu dan $\mathrm{pH}$ yang bervariasi.

2. Untuk mengetahui aktivitas minimal enzim amiloglukosidase dari Aspergillus niger pada kombinasi suhu dan $\mathrm{pH}$ yang bervariasi. 
Fatmawati Nur, Uji Aktivitas Enzim Amiloglukosidase dari Aspergillus Niger pada..._29

\section{TINJAUAN PUSTAKA}

\section{Enzim Amiloglukosidase}

Dikenal ada dua tipe enzim yaitu enzim ekstraselluler atau eksoenzim dan enzim intraselluler atau endoenzim. Fungsi utama eksoenzim ialah melangsungkan perubahan seperlunya pada nutrien di sekitarnya sehingga memungkinkan nutrien tersebut memasuki sel. Enzim intraselluler mensintesis bahan selluler dan menguraikan nutrien untuk menyediakan energi yang dibutuhkan oleh sel(Pelczar, 1985).

Amiloglukosidase adalah salah satu jenis enzim ekstraselluler, tergolong ke dalam kelompok enzim amilase. Amilase adalah enzim yang menghidrolisis pati. Hidrolisis pati pertama-tama menghasilkan polimer berantai pendek yang disebut dekstrin, kemudian disakarida, maltosa, dan akhirnya glukosa. Glukosa merupakan jenis gula sederhana yang derajat kemanisannya lebih rendah dari fruktosa (Rahman, 1992).

Enzim amiloglukosidase merupakan enzim yang dapat menguraikan ikatan glikosidik $\alpha-1.4, \alpha-1.6, \alpha-1.3$, dan melepaskan unit glukosa mulai dari ujung rantai non pereduksi dalam amilosa, amilopektin, dan glikogen. Pada kenyataannya, amiloglukosidase mengalami kesulitan dalam menghidrolisis ikatan glikosidik $\alpha-1.6$, namun hal ini dapat diatasi dengan adanya enzim amilase sehingga hasil hidrolisis kedua enzim secara bersama-sama akan lebih sempurna (Hardjo, 1989).

Bagian gugus prostetik terdiri dari molekul organik yang berat molekulnya lebih rendah daripada apoenzim, dinamakan koenzim. Beberapa enzim mengandung vitamin sebagai pelengkap. Tetapi dalam beberapa hal, bagian gugus prostetik suatu enzim dapat berupa logam untuk menjadi teraktivasi. Ion-ion itu dianggap sebagai koezim anorganik (kofaktor), dan keduanya dibutuhkan untuk membuat suatu enzim menjadi aktif (Pelczar, 1985).

Enzim dapat diperoleh dari jaringan tumbuhan, hewan, dan mikroorganisme yang terseleksi. Dari sumber tumbuhan dan hewan mungkin timbul banyak persoalan, yakni untuk enzim yang berasal dari tumbuhan, persoalan yang timbul adalah variasi musim, konsentrasi rendah dan biaya proses yang tinggi. Sedangkan yang diperoleh dari hasil samping industri daging mungkin persediaan enzimnya terbatas dan ada persaingan dengan pemanfaatan lain (Smith, 1993). 
Oleh karena itu peningkatan sumber enzim sedang dilakukan yaitu mikroba penghasil enzim yang sudah dikenal atau penghasil enzim baru lainnya, dengan cara membiakkan mikroba penghasil enzim yang dikehendaki pada media tertentu kemudian diekstraksi dan akhirnya dimurnikan. Ada beberapa keuntungan yang diperoleh dengan menggunakan enzim dari mikroba, yaitu: biaya produksi relatif rendah, dapat diproduksi dalam waktu singkat, serta mudah dikontrol. Kecepatan produksi enzim dari mikroba akan meningkat dengan berkembangnya seleksi mikroba, induksi mutan dan perbaikan kondisi kultur untuk pertumbuhan (Smith, 1993).

Enzim amiloglukosidase dapat diperoleh dari beberapa jenis mikroba yang mengeluarkan enzim ini ke lingkungannya dan telah diusahakan secara komersial, antara lain diproduksi dari Aspergillus, Rhizopus (Winarno, 1995), Endomycopsis, Mucor, Penicillium, Saccharomyces, dan Trichoderma (Hardjo, 1989). Produksi amiloglukosidase oleh Aspergillus niger L.51/NRRL All-164 dengan molases sebagai sumber karbon, menunjukkan kondisi optimal produksi pada suhu $35^{\circ} \mathrm{C}, \mathrm{pH}$ 4.5, kecepatan aerasi $1 \mathrm{rpm}$, dan waktu fermentasi 96 jam, ke dalam medium ditambahkan induser sebanyak $2 \mathrm{~g} / 1$. Tetapi pada umumnya amiloglukosidase bekerja secara optimal pada kisaran suhu 40-60 ${ }^{\circ} \mathrm{C}$ dan $\mathrm{pH}$ berkisar 4.5-5.0 (Rahman, 1992).

Dalam pelaksanaannya enzim mikroba didapat dari mikroorganisme tertentu saja dan terutama lebih banyak dari mikroorganisme yang bersifat tidak patogen, tidak memproduksi bahan toksik dan mempunyai stabilitas biologi yang tinggi.

\section{Faktor-faktor yang Mempengaruhi Aktivitas Enzim}

Keadaan yang mempengaruhi aktivitas enzim diantaranya ialah konsentrasi enzim, konsentrasi substrat, $\mathrm{pH}$, suhu, pengaruh air, pengaruh hasil akhir, aktivator, dan inhibitor (Pelczar, 1985).

Terdapat hubungan optimum antara konsentrasi enzim dan substrat bagi aktivitas maksimum. Demikian juga, setiap enzim berfungsi secara optimal pada $\mathrm{pH}$ dan temperatur tertentu. Penyimpangan dari keadaan optimum mengakibatkan berkurangnya aktivitas enzim dengan nyata. Keragaman $\mathrm{pH}$ yang ekstrim bahkan dapat merusak enzim, seperti juga suhu tinggi. Pendidihan akan menyebabkan 
denaturasi enzim, sementara suhu rendah pada praktisnya menghentikan aktivitas enzim tetapi tidak menghancurkannya. Banyak enzim dapat diawetkan dengan cara menyimpan pada suhu sekitar $0{ }^{\circ} \mathrm{C}$ atau kurang (Pelczar, 1985).

Konsentrasi enzim dan substrat yang dua kali kekuatannya, maka reaksi berlangsung dua kali lipat lebih giat. Namun kadang-kadang hasil akhir yang tertimbun bisa menghambat kegiatan enzim (Dwidjosepoetro, 1989).

Penambahan zat-zat kimia dapat menambah kegiatan seluruh enzim, misalnya garam-garam dari logam alkali tanah dalam konsentrasi encer. Ion-ion Kobalt, Mangan, Nikel, Magnesium dan Khlor merupakan penggiat bagi enzim tertentu. Di samping itu ada pula zat kimia yang menghambat laju kerja enzim seperti garamgaram dari logam berat seperti Air raksa. Zat penghambat dapat bersaing jika strukturnya mirip dengan struktur molekul substrat, dapat pula berupa zat penghambat tak bersaing jika strukturnya mirip dengan struktur molekul enzim, terutama bagian prostetiknya (Dwidjosepoetro, 1989).

\section{METODE PENELITIAN}

Penelitian dilakukan dalam beberapa tahapan untuk pengujian aktivitas enzim amiloglukosidase pada kombinasi suhu dan $\mathrm{pH}$ yang bervariasi setelah diproduksi oleh Aspergillus niger. Urutan tahapan penelitian sebagai berikut :

\section{Pembuatan Inokulum}

Aspergillus niger yang ditumbuhkan pada medium PDA umur 4 × 24 jam, suhu kamar ditambahkan cairan yang terdiri dari $0.1 \%$ Tween 80 dan $0.9 \% \mathrm{NaCl}$ fisiologis, kemudian dikeruk dan dikocok hingga semua spora mikroorganismenya lepas. Suspensi ini digunakan sebagai inokulum yang akan dimasukkan ke dalam medium fermentasi.

\section{Produksi Enzim Amiloglukosidase}

Medium produksi terdiri dari : limbah markisa (8\%), $\mathrm{NaH}_{2} \mathrm{PO}_{4}(4.7 \%)$, $\mathrm{CaCl}_{2}(0.1 \%)$, $\mathrm{KCl}(0.02 \%)$, dan $\mathrm{MgCl}_{2} \cdot 6 \mathrm{H}_{2} \mathrm{O}$ (0.02\%) diinokulasikan dengan Aspergillus niger FNCC 6018 dari inoculum sebanyak 1 ml dengan kerapatan spora 
$10^{7} / \mathrm{ml}$ pada volume media $100 \mathrm{ml}$, difermentasikan pada suhu kamar, $\mathrm{pH}$ 4.5. Sampling dilakukan pada jam ke 96 waktu fermentasi yang diekstraksi dengan sentrifuge 3000 rpm selama 10 menit, kemudian ditentukan aktivitas enzim amiloglukosidase secara sacharifying.

\section{Penentuan Aktivitas Enzim Amiloglukosidase}

Aktivitas enzim amiloglukosidase ditentukan dengan urutan langkah sebagai berikut :

a. Satu ml larutan $1 \%$ pati terlarut diisikan ke dalam 22 tabung reaksi, 21 tabung reaksi diinkubasikan dalam penangas air suhu $100^{\circ} \mathrm{C}$, dan 1 tabung untuk standar diinkubasikan ke dalam penangas air suhu $42^{\circ} \mathrm{C}$, masing-masing selama 5 menit.

b. Ditentukan $\mathrm{pH}$ perlakuan, masing-masing 4.5, 5.0, dan 5.5. Ke dalam tabung yang telah diatur pHnya ditambahkan $0.1 \mathrm{ml}$ enzim hasil pengenceran 10 kali (kecuali tabung reaksi untuk standar, ditambahkan $0.1 \mathrm{ml}$ air suling), kemudian diinkubasikan pada suhu pengujian, masing pada suhu $35^{\circ} \mathrm{C}, 40{ }^{\circ} \mathrm{C}, 45^{\circ} \mathrm{C}, 50{ }^{\circ} \mathrm{C}$, $55^{\circ} \mathrm{C}, 60^{\circ} \mathrm{C}$, dan $65^{\circ} \mathrm{C}$. Reaksi dibiarkan selama 10 menit.

c. Setelah 10 menit, reaksi dihentikan dengan jalan memindahkan tabung-tabung tersebut ke dalam penangas air $100{ }^{\circ} \mathrm{C}$ selama 10 menit. Hasil hidrolisis selama 10 menit tersebut ditentukan kadar glukosanya dengan metode SomogyNelson. Urutan langkah penentuan tersebut adalah sebagai berikut:

- Ke dalam masing-masing tabung reaksi ditambahkan $1.6 \mathrm{ml}$ reagen Nelson A, kemudaian $0.4 \mathrm{ml}$ reagen Nelson B. Campuran dikocok, kemudian mulut tabung ditutup kelereng dan dipanaskan dalam penangas air suhu $100^{\circ} \mathrm{C}$ selama 10 menit, kemudian didinginkan dalam es selama 5 menit.

- Ke dalam masing-masing tabung ditambahkan $2 \mathrm{ml}$ reagen Arsenomolibdat dan $4.9 \mathrm{ml}$ air suling. Tabung dikocok dengan kuat sambil menutup mulut tabung dengan ibu jari hingga seluruh gas $\mathrm{CO}_{2}$ keluar. Hasilnya disentrifuge pada 5000 rpm selama 10 menit (jika terjadi endapan), kemudian diukur OD nya pada spektrofotometer dengan panjang gelombang $520 \mathrm{~nm}$. 
d. Aktivitas enzim ditentukan berdasarkan persamaan berikut:

$$
\mathrm{AE}=\frac{\mathrm{F}_{\mathrm{s}} \times \mathrm{A} \times \mathrm{Kxf}_{\mathrm{o}}}{\mathrm{t}} \times 10^{-3}
$$

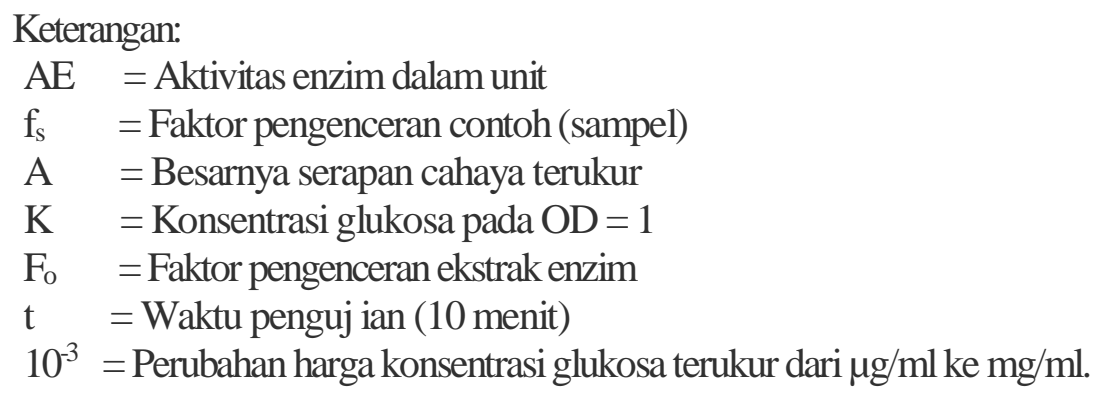

Satu unit aktivitas enzim amiloglukosidase ditetapkan sebagai $1 \mu$.mol glukosa yang dihasilkan setiap menit.

\section{HASIL DAN PEMBAHASAN}

Pengujian aktivitas enzim amiloglukosidase yang dihasilkan oleh Aspergillus niger dengan media fermentasi limbah markisa dilakukan pada kombinasi suhu dan $\mathrm{pH}$ yang bervariasi, dilakukan dengan tiga kali ulangan, dan didapatkan hasil uji aktivitasnya yang dilakukan dengan uji Wilayah Berganda Duncan seperti tampak pada tabel 1 .

Perlakuan $\mathrm{pH}$ yang diberikan terhadap pengujian aktivitas enzim amiloglukosidase adalah 4.5, 5.0, dan 5.5, didasarkan pada $\mathrm{pH}$ optimum pertumbuhan kapang, yang berarti bahwa $\mathrm{pH}$ aktivitas enzim yang mempengaruhi pertumbuhannya berada pada kisaran tersebut, karena pada dasarnya pertumbuhan mikroba itu adalah akibat adanya kerja enzim (Pelczar, 1985). Sedangkan perlakuan suhu adalah $35^{\circ} \mathrm{C}, 40^{\circ} \mathrm{C}, 45^{\circ} \mathrm{C}, 50^{\circ} \mathrm{C}, 55^{\circ} \mathrm{C}, 60^{\circ} \mathrm{C}$, dan $65^{\circ} \mathrm{C}$, didasarkan pada penelitian terdahulu bahwa suhu optimum untuk aktivitas enzim amiloglukosidase berkisar $40-60^{\circ} \mathrm{C}$ (Rahman, 1992).

Dari hasil analisis statistik didapatkan perlakuan-perlakuan yang diberikan berupa kombinasi $\mathrm{pH}(\mathrm{P})$ dan suhu $(\mathrm{T})$ yang bervariasi itu, tampak terdapat perbedaan yang nyata antara satu perlakuan dengan perlakuan lainnya. 
Dengan adanya perbedaan antara perlakuan, maka dilakukanlah uji Wilayah Berganda Duncan (WBD) untuk mengetahui perlakuan yang berpengaruh terhadap aktivitas enzim amiloglukosidase dari Aspergillus niger seperti tampak pada tabel 1.

Pada tabel 1 terlihat bahwa aktivitas maksimum enzim amiloglukosidase berada pada kombinasi perlakuan $\mathrm{P}_{2} \mathrm{~T}_{6}\left(\mathrm{pH} 5.0\right.$ dan suhu $60^{\circ} \mathrm{C}$ ) sebesar 15.,6493 unit/ml. Perlakuan ini memperlihatkan perbedaan yang nyata (taraf $5 \%$ ) dengan perlakuan lainnya, kecuali untuk perlakuan $\mathrm{P}_{1} \mathrm{~T}_{6}\left(\mathrm{pH} 4.5\right.$ dan suhu $\left.60^{\circ} \mathrm{C}\right)$ dengan aktivitas 14.3773 unit/ml, tidak berbeda nyata (taraf $5 \%)$.

Tabel 1. Hasil Uji Wilayah Berganda Duncan pada Taraf $5 \%$ terhadap Perlakuan kombinasi pH (P) dan suhu (T) Aktivitas Enzim Amiloglukosidase dari Aspergillus niger

\begin{tabular}{|c|c|}
\hline Kombinasi pH dan Suhu & Aktivitas Enzim Amiloglukosidase (Unit/ml) \\
\hline$\overline{\mathrm{P}_{2} \mathrm{~T}_{6}}$ & $15.6493 \mathrm{a}$ \\
\hline $\mathrm{P}_{1} \mathrm{~T}_{6}$ & $14.3770 \mathrm{ab}$ \\
\hline $\mathrm{P}_{2} \mathrm{~T}_{5}$ & $14.0543 \mathrm{~b}$ \\
\hline $\mathrm{P}_{3} \mathrm{~T}_{5}$ & 13.8417 be \\
\hline $\mathrm{P}_{1} \mathrm{~T}_{7}$ & 13.4530 bed \\
\hline $\mathrm{P}_{1} \mathrm{~T}_{5}$ & 13.1963 bed \\
\hline $\mathrm{P}_{3} \mathrm{~T}_{6}$ & 13.0680 bcde \\
\hline $\mathrm{P}_{2} \mathrm{~T}_{7}$ & 13.0680 bcde \\
\hline $\mathrm{P}_{2} \mathrm{~T}_{4}$ & 12.3823 cde \\
\hline $\mathrm{P}_{1} \mathrm{~T}_{4}$ & $12.1953 \mathrm{def}$ \\
\hline $\mathrm{P}_{3} \mathrm{~T}_{4}$ & 12.1843 def \\
\hline $\mathrm{P}_{2} \mathrm{~T}_{3}$ & 11.6050 ef \\
\hline $\mathrm{P}_{1} \mathrm{~T}_{3}$ & 11.5243 ef \\
\hline $\mathrm{P}_{3} \mathrm{~T}_{3}$ & 11.5097 ef \\
\hline $\mathrm{P}_{2} \mathrm{~T}_{2}$ & $10.8020 \mathrm{fg}$ \\
\hline $\mathrm{P}_{3} \mathrm{~T}_{2}$ & $10.7800 \mathrm{fg}$ \\
\hline $\mathrm{P}_{2} \mathrm{~T}_{1}$ & 10.7727 fg \\
\hline $\mathrm{P}_{3} \mathrm{~T}_{1}$ & $10.7067 \mathrm{fg}$ \\
\hline $\mathrm{P}_{1} \mathrm{~T}_{2}$ & 9.5150 ghi \\
\hline $\mathrm{P}_{1} \mathrm{~T}_{1}$ & $9.1190 \quad$ hi \\
\hline $\mathrm{P}_{3} \mathrm{~T}_{7}$ & 7.9823 \\
\hline
\end{tabular}

Huruf yang sama menyatakan tidak ada beda nyata pada taraf uji $5 \%$

Keterangan: $\mathrm{P}_{1}(\mathrm{pH} 4.5), \mathrm{P}_{2}$ (pH 5.0), $\mathrm{P}_{3}\left(\mathrm{pH} 5.5\right.$ ), $\mathrm{T}_{1}$ (suhu $35^{\circ} \mathrm{C}$ ), $\mathrm{T}_{2}$ (suhu $40{ }^{\circ} \mathrm{C}$ ), $\mathrm{T}_{3}$ (suhu $45^{\circ} \mathrm{C}$ ), $\mathrm{T}_{4}\left(\right.$ suhu $50^{\circ} \mathrm{C}$ ), $\mathrm{T}_{5}\left(\right.$ suhu $55^{\circ} \mathrm{C}$ ), $\mathrm{T}_{6}$ (suhu $60^{\circ} \mathrm{C}$ ), $\mathrm{T}_{7}$ (suhu $65^{\circ} \mathrm{C}$ ). 
Kondisi perlakuan $\mathrm{P}_{2} \mathrm{~T}_{6}\left(\mathrm{pH} 5.0\right.$ dan suhu $\left.60^{\circ} \mathrm{C}\right)$ merupakan kondisi optimum untuk aktivitas enzim amiloglukosidase disebabkan karena pada keadaan tersebut, $\mathrm{pH}$ maupun suhu saling berinteraksi memberikan lingkungan yang sesuai untuk aktivitas maksimum enzim tersebut.

Pada pH 5.0 merupakan kondisi yang tepat untuk gugus pemberi atau penerima proton pada sisi katalitik enzim berada pada tingkat ionisasi yang diinginkan. Dan pada kondisi yang sama, suhu $60^{\circ} \mathrm{C}$ merupakan suhu yang tepat untuk sisi katalitik enzim dapat mengikat dengan bagus molekul substrat yang mengalami perenggangan akibat kenaikan suhu (Winarno, 1995).

Dari tabel 1 juga terlihat bahwa aktivitas minimum enzim amiloglukosidase dari Aspergillus niger adalah pada perlakuan $\mathrm{P}_{3} \mathrm{~T}_{7}\left(\mathrm{pH} 5.5\right.$ dan suhu $\left.65^{\circ} \mathrm{C}\right)$ sebesar 7.9823 unit/ml. Perlakuan ini berbeda nyata (taraf $5 \%$ ) dengan perlakuan lainnya, tapi tidak beda nyata (taraf $5 \%$ ) dengan perlakuan $\mathrm{P}_{1} \mathrm{~T}_{1}\left(\mathrm{pH} 4.5\right.$ dan suhu $\left.35^{\circ} \mathrm{C}\right)$ dengan aktivitas sebesar 9.1190 unit $/ \mathrm{ml}$ dan perlakuan $\mathrm{P}_{1} \mathrm{~T}_{2}\left(\mathrm{pH} 4.5\right.$ dan suhu $\left.40^{\circ} \mathrm{C}\right)$ dengan aktivitas $9.5150 \mathrm{unit} / \mathrm{ml}$.

Perlakuan $\mathrm{P}_{3} \mathrm{~T}_{7}\left(\mathrm{pH} 5.5\right.$ dan suhu $65^{\circ} \mathrm{C}$ ) adalah kondisi dimana enzim amiloglukosidase tidak maksimum melaksanakan aktivitasnya. Ini disebabkan karena pada kondisi tersebut enzim telah mengalami denaturasi akibat $\mathrm{pH}$ dan suhu tinggi. Keadaan ini juga berlaku pada perlakuan $\mathrm{P}_{1} \mathrm{~T}_{1}(\mathrm{pH} 4.5$ dan suhu $35 " \mathrm{C})$ dan perlakuan $\mathrm{P}_{1} \mathrm{~T}_{2}(\mathrm{pH} 4.5$ dan suhu $40^{\circ} \mathrm{C}$ ) dimana enzim amiloglukosidase tidak bekerja maksimum pada $\mathrm{pH}$ dan suhu rendah.

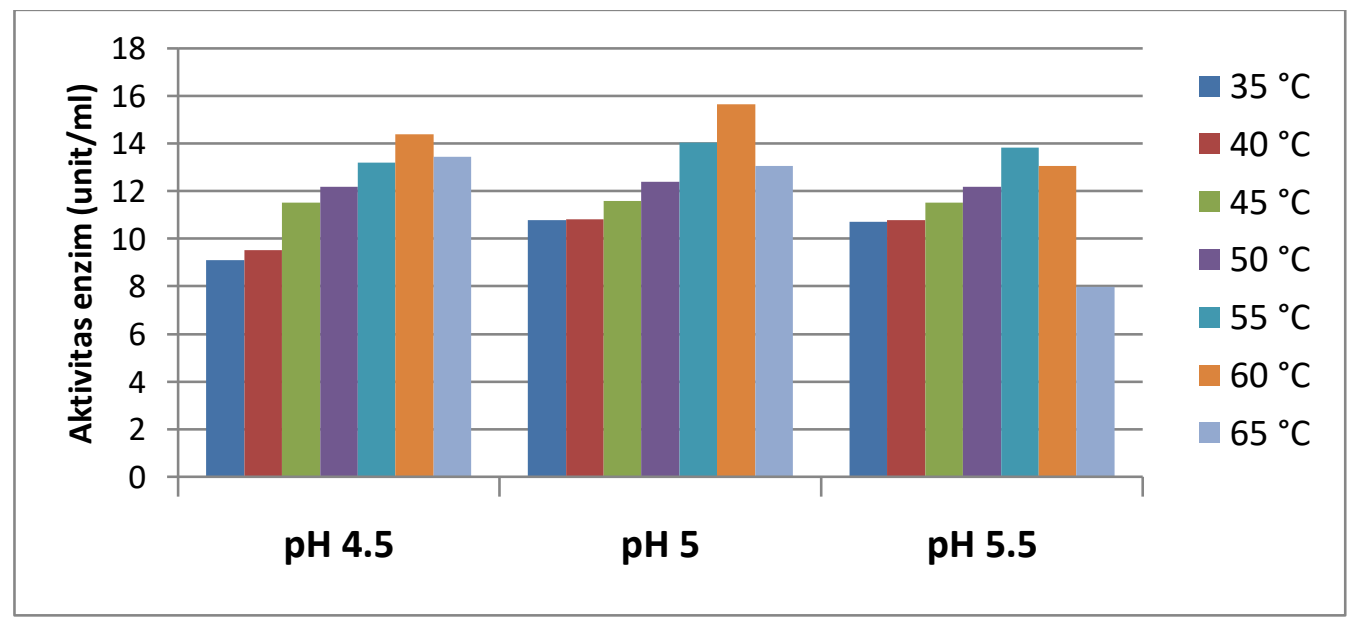

Gambar 1. Histogram suhu optimum aktivitas enzim amiloglukosidase dari Aspergillus niger pada $\mathrm{pH}$ yang bervariasi 
Kenyataan adanya aktivitas maksimum dan aktivitas minimum akibat perbedaan perlakuan menunjukkan bahwa kombinasi perlakuan yang diberikan sangat mempengaruhi aktivitas enzim amiloglukosidase.

Jika ditinjau secara khusus, hasil pengujian menunjukkan bahwa $\mathrm{pH}$ optimum untuk aktivitas enzim ini adalah 5.0 untuk semua perlakuan suhu kecuali pada suhu $65^{\circ} \mathrm{C}$ pH optimumnya 4.5 seperti tampak pada gambar 1.

Pada gambar 1 tampak bahwa naiknya $\mathrm{pH}$ memacu aktivitas enzim dan kemudian turun lagi setelah melewati $\mathrm{pH}$ tertentu yang merupakan $\mathrm{pH}$ optimumnya.

Laju reaksi berkurang pada kedua sisi $\mathrm{pH}$ optimum, disebabkan oleh protein enzim dapat mengalami denaturasi akibat $\mathrm{pH}$ ekstrim tinggi atau rendah. Hal ini didukung oleh Winarno (1995) bahwa aktivitas enzim hanya pada $\mathrm{pH}$ tertentu disebabkan oleh karena enzim mengalami denaturasi, protein enzim memerlukan gugus asam amino yang terionisasikan pada rantai samping yang mungkin aktif hanya pada satu keadaan ionisasi, dan mungkin juga substrat memperoleh atau kehilangan proton dan reaktif dalam satu bentuk muatan.

Demikian pula halnya dengan perlakuan suhu yang dikombinasikan dengan $\mathrm{pH}$ memperlihatkan hasil pengujian aktivitas optimum pada suhu $60^{\circ} \mathrm{C}$ untuk $\mathrm{pH} 4.5$ dan 5.0, sedangkan untuk pH 5.5 suhu optimumnya adalah $55^{\circ} \mathrm{C}$ seperti tampak pada gambar 2 .

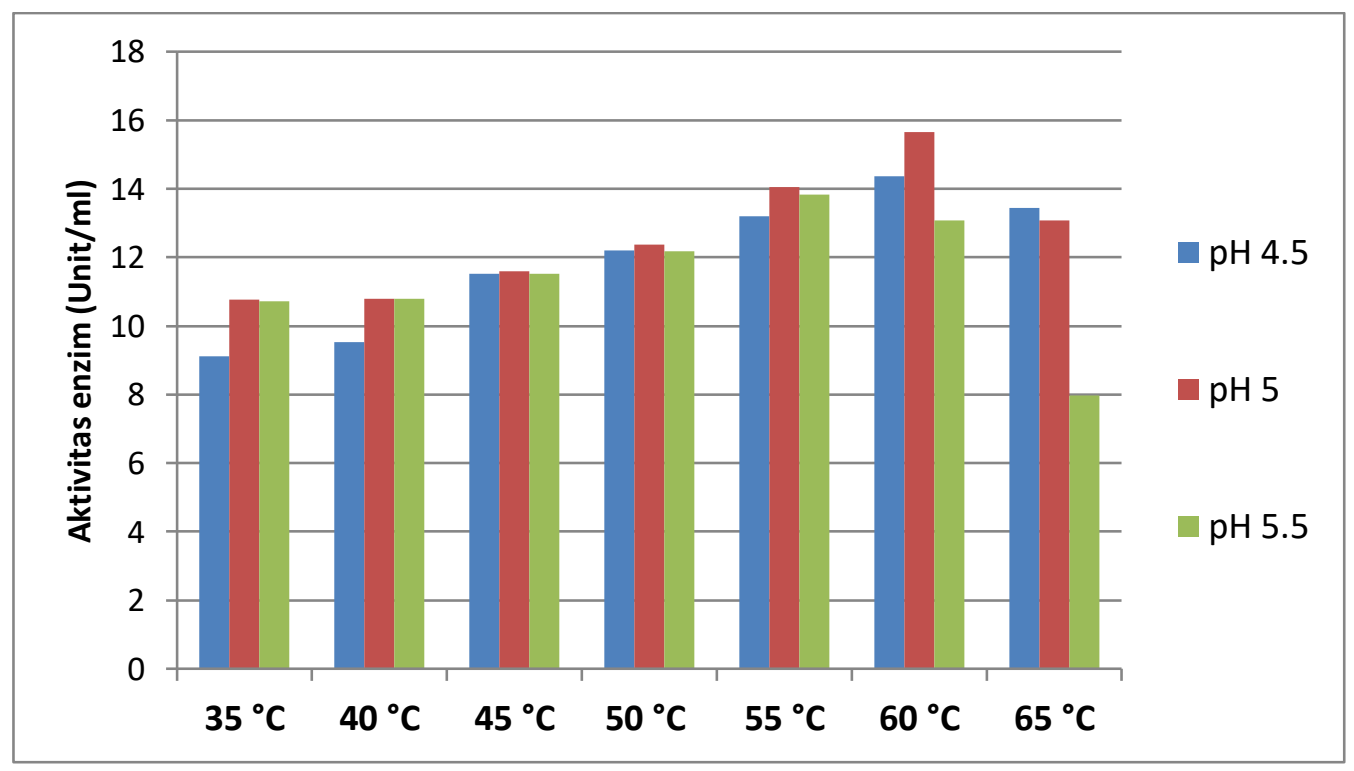

Gambar 2. HistogrampH optimum aktivitas enzim amiloglukosidase dari Aspergillus niger pada suhu yang bervariasi 
Pada gambar 2 tampak bahwa kenaikan suhu mengakibatkan kenaikan laju aktivitas yang kemudian sampai suhu tertentu, aktivitas kembali turun. Suhu puncak aktivitas disebut suhu optimum aktivitas enzim. Setelah melewati batas tersebut, enzim mengalami denaturasi oleh panas sebagaimana sifat protein, seperti yang dikemukakan oleh Page (1985), bahwa pengaruh suhu dapat mengaktifkan enzim, tetapi suhu yang terlalu tinggi dapat merusak enzim tersebut.

\section{KESIMPULAN}

Dari hasil pengujian aktivitas enzim amiloglukosidase dari Aspergillus niger pada kombinasi suhu dan $\mathrm{pH}$ yang bervariasi, didapat kesimpulan sebagai berikut:

1. Aktivitas maksimal enzim amiloglukosidase dari Aspergillus niger adalah pada kombinasi suhu $60{ }^{\circ} \mathrm{C}$ dan $\mathrm{pH} 5.0$ sebesar 15.6493 (unit $/ \mathrm{ml}$ ).

2. Aktivitas minimal enzim amiloglukosidase dari Aspergillus niger adalah pada kombinasi suhu $65^{\circ} \mathrm{C}$ dan $\mathrm{pH} 5.5$ sebesar 7.9823 (unit $/ \mathrm{ml}$ ).

\section{DAFTAR PUSTAKA}

Dwidjosepoetro, D. (1989), "Pengantar Fisiologi Tumbuhan", Gramedia, Jakarta.

Gaman, P.M., Sherrington, K.B. (1992), "Ilmu Pangan. Pengantar Ilmu Nutrisi dan Mikrobiologi", Terjemahan oleh : Mardijati Gardjito, Gadjah Mada University Press, Yogyakarta.

Hardjo, S., Indrasti, N.S., Bantacut, T. (1989), "Biokonversi : Pemanfaatan Limbah Industri Pertanian", PAU Pangan dan Gizi, IPB, Bogor.

Kertesz, Z.I. and R.I. Me Collogen (1976), "Enzim Acting on Pectin Subtances" dalam "Advances in Carbohydrat and Biochemistry", (Tipson, R.S. and H. Derek, ed), Academic Press, London.

Pelczar, M.J. dan Chan (1985), "Dasar-dasar Mikrobiologi 1", Terjemahan oleh R.S. Hadioetomo, T. Imas, S.S. Tjitrosoepomo, S.L. Angka, Universitas Indonesia Press, Jakarta.

Rahman, A. (1992), "Teknologi Fermentasi", Arcan, Jakarta. (1992), "Teknologi Fermentasi Industrial", Arcan, Jakarta.

Smith, I.E. (1993), "Prinsip Bioteknologi", Terjemahan oleh V.F. Sumo, B.Sumantri, dan Subono, Gramedia Pustaka Utama, Jakarta. 
38 _Jurnal Teknosains, Volume 12, Nomor 1, Januari-Juni 2018, hlm. 27 -3 8

Winarno, F.G. (1995), "Enzim Pangan", Gramedia Pustaka Utama, Jakarta.

Page, D.S (1985), "Prinsip-prinsip Biokimia ", Terjemahan oleh R. Soendoro, Erlangga, Jakarta. 